\title{
Strength Characterization of Cement Stabilized and Fiber Reinforced Clay-Pond Ash Mixes
}

\author{
Deepak Gupta $^{1}$ (D) Arvind Kumar ${ }^{1}$
}

Received: 6 May 2016/Accepted: 15 September 2016/Published online: 25 October 2016

(C) Springer International Publishing Switzerland 2016

\begin{abstract}
This paper presents the experimental results obtained from tests conducted on clayey soil specimen stabilized with pond ash (PA) and cement and reinforced with randomly distributed fibers. The amount of PA and cement were varied from $0-50$ and $0-6 \%$ respectively by dry weight of the soil. In order to understand the influence of admixture on the strength properties of clay, compaction tests, unconfined compression tests (UCS), split tensile strength (STS) tests and California bearing ratio tests (CBR) were conducted. In addition scanning electron microscopy and X-ray diffraction tests were carried out on certain samples in order to study the surface morphological characteristics and hydraulic compounds, which were formed. The specimens were tested for their strength behaviour at different curing periods. The obtained results have shown that addition of mixtures leads to a decrease in the maximum dry density and increase in optimum moisture content. The results also indicate that the proposed method is very effective to improve the strength of the clayey soil in terms of UCS, STS and CBR tests.
\end{abstract}

Keywords Fibers · Admixtures - MDD $\cdot$ UCS $\cdot$ CBR $\cdot$ PA

\section{Introduction}

Due to the weak nature of soil, the construction of buildings and other civil engineering structures on it may be very risky. In order to improve the desirable characteristics

Deepak Gupta

deepakg757@gmail.com

1 Department of Civil Engineering, Dr B R Ambedkar National Institute of Technology Jalandhar, Jalandhar, Punjab, India of soil such as bearing capacity, shear strength and permeability, several ground improvement techniques can be adopted.

To maintain the economy in construction, an alternative approach of treating the soil with cement has become an effective solution for most of the earth structures. The soil stabilization can be carried out using different types of binder materials such as lime, cement, etc. depending on soil type. A recent investigation has reported the utilization of lime in combination with fly ash to achieve the pozzolanic effect for the stabilization of sub-grade soil [1]. The incorporation of cement increases the rate of strength achievement but the drawbacks of shrinkage and cracking phenomenon still occur when used as a base course [2, 3].

Remarkable improvements and modifications in the engineering characteristics of soils can be achieved using fiber inclusions. Various types of tests have been performed by researchers on fiber reinforced soils such as triaxial tests, unconfined compression tests, CBR tests, direct shear tests, and tensile and flexural strength tests [4-22]. The incorporation of randomly distributed fibers offers the prime advantage of overcoming the weak potential planes which usually develop parallel to the oriented reinforcement [7]. It has been observed that fiber concentration and fiber distribution effect the strength of cement stabilized and randomly distributed fiber reinforced soil [13]. Besides unconfined compression tests, splitting tensile tests, and saturated drained triaxial compression tests have also been carried out to study the benefits of utilizing randomly distributed polyethylene fibers obtained from plastic wastes, alone and combined with rapid hardening Portland cement to improve the engineering behaviour of uniform sand [14]. The UCS value of highly compressible clay has been found to be increased with the fiber inclusion and has been further increased by mixing 
fibers in clay sand mixtures [16]. The influence of fiber concentration as well as fiber distribution significantly affect the on the strength of fiber-reinforced cemented sand [21].

Power plants produce large quantities of fly ash (FA) and bottom ash as by-product all over the world. The drawbacks of PA deposits include their poor bearing capacity and very low density. It has been estimated that nearly 20,000 ha of land area gets covered up by millions of tons of PA deposits in India [23]. The leachates which emanate from the ash ponds can cause contamination of both surface water and groundwater bodies and soil due to presence of toxic elements and heavy metals [23].

The engineering properties of pond ash have been improved using several attempts among which the utilization of lime/cement in the pond ash by mechanical mixing has been the most effective approach. Studies have been carried out on fiber reinforced silty sand mixed with pond ash. The experimental results have shown that there is an increase in peak compressive strength, CBR value, peak friction angle, and ductility of the specimens with the inclusion of fibres in soils [23]. California bearing ratio of pond ash has been found to improve with the addition of lime [24]. An experimental study has shown that increase in compactive efforts lead to an increase in MDD and simultaneous decrease in OMC [25]. It has been concluded that the cement stabilized and fiber reinforced clay mixed with optimum percentage of rice husk ash and pond ash can be an effectively used as geotechnical fill materials [26]. Improvement in strength and durability characteristics has been observed using lime in class $\mathrm{F}$ fly ash [23]. The effectiveness of using RHA and PA in improving the quality of sub-grade for road construction has also been reported, wherein the addition of PA or RHA has shown a considerable influence on compaction characteristics of alluvial soil. MDD of mixed soil decreases with increase in added percentage of either of PA or RHA and OMC increase [27]. In order to study the suitability of stabilized pond ash for road base and sub-base construction, a series of laboratory test were performed. The results have shown that individual utilization of Class F PA or combined utilization with different dosages of lime (4, 6 and $10 \%)$ and Phosphogypsum $(0.5$ and $1.0 \%)$ can be suitable for construction of road base and sub-base [28].

Different studies have shown that pond ash and fibers both have potential of improving strength of soil, but in each case there is an optimum value of content after which improvement in strength is marginal or it may decrease which shows that there is a limitation in improvement of strength through addition of pond ash [29]. But further improvement in the strength of soil-pond ash mix can be achieved using some additional treatment. For instance, the combined effect of pond ash, fibers and cement can further improve the strength of soil $[26,28]$. But the combined effect of pond ash and fibers on the properties of soil is yet required further to be studied. In the present study, compaction behaviour of soil mixed with different combination of PA, cement and fibers has been investigated because the compaction behaviour is important for structures like pavements and embankments. Additionally, the strength behaviour has also been determined using UCS, STS and CBR tests.

\section{Experimental Investigation}

\section{Materials}

Materials used in the study are same as used by authors' in their previous paper [26].

\section{Soil}

Kaolin clay was used in the present study. Thus the soil is classified as CL (clay with low plasticity) according to unified soil classification system (USCS).The particle size distribution curve is shown in Fig. 1.

\section{Pond Ash}

Class F pond ash of light grey colour was used in the study. The PA is non plastic in nature having specific gravity 2.10. The composition of various chemical compounds present in PA was $52.70 \% \mathrm{SiO}_{2}, 32.00 \% \mathrm{Al}_{2} \mathrm{O}_{3}, 4.90 \%$ $\mathrm{Fe}_{2} \mathrm{O}_{3}, 1.12 \% \mathrm{CaO}$ and $1.08 \% \mathrm{MgO}$, with $4.6 \%$ loss on ignition and $3.6 \%$ others. The particle size distribution curve has been given in Fig. 1 .

\section{Fibers}

The reinforcing material used in the current study was polypropylene fibers which were fibrillated type having cut

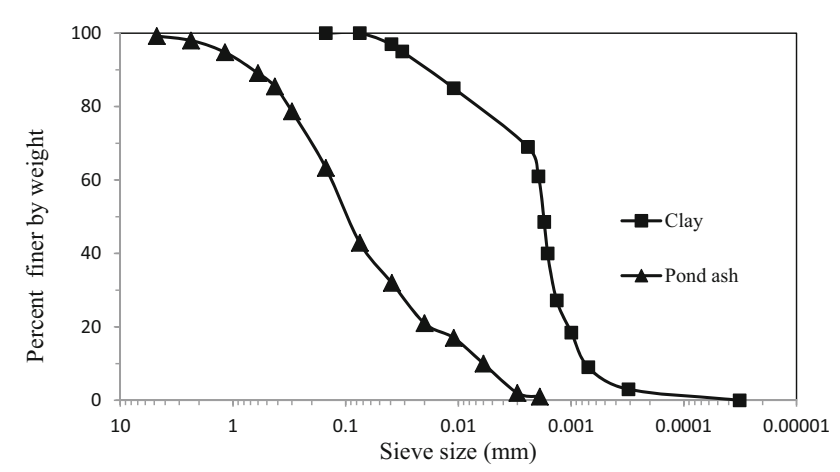

Fig. 1 Particle size distribution of clay and pond ash 
length of 3, 6 and $12 \mathrm{~mm}$. The fibers had specific gravity of 0.9-0.91, water absorption ( $24 \mathrm{~h}$ duration) of $0.3 \%$, and had excellent acid and alkali resistance.

\section{Ordinary Portland Cement (OPC-43 grade)}

The Ordinary Portland cement (OPC) having initial and final setting times of 30 and $600 \mathrm{~min}$ was used in the study.

\section{Experimental Programme and Methodology}

A comprehensive series of experimental tests were performed on the pond ash-clay mixed (mixed in different proportions) with cement and fibers. The experimental programme involved in the present investigation comprised the following tests: Modified Proctor compaction test, UCS, STS and CBR tests. In addition to that SEM/EDS and XRD were conducted on various samples in order to study the surface morphological characteristics and hydraulics compounds, which were formed. All tests were conducted on samples prepared at maximum dry density and optimum moisture content obtained from modified compaction tests. The specimens were cured in humidity control chamber for 7, 14, and 28 days. For each mix, two samples were prepared.

Table 1 presents a summary of tests performed for various combinations of materials. The clay was replaced by pond ash contents of 10,20,30,40 and $50 \%$ and cement content of 2, 4 and $6 \%$, on dry weight basis. Further, four values of fibers content, i.e., 0.5, 1, 1.5 and $2 \%$ and fiber length 3, 6 and $12 \mathrm{~mm}$ were considered for the best combination.

\section{Specimen Preparation and Testing Procedures}

\section{SEM/EDS Observations for Surface Characterization and Elemental Composition}

The surface morphological features and presence of different elements present in the samples were examined using scanning electron microscopy (JEOL-JSM 6510). Microstructural analyses of selected samples, taken from the centre of the crushed UCS sample, were conducted. For this, the broken pieces or the fragments which were intact in themselves were subjected to SEM analysis. This was done to ensure that the fiber arrangement does not get distorted or disturbed prior to SEM testing. These broken pieces were further air dried. The dried pieces not exceeding $2 \mathrm{~mm}$ in size were used for SEM testing. The samples were coated with conductive coating prior to image observation. The coated samples were then loaded into the JSM 6510 scanning electron microscope for capturing images.

\section{XRD Analysis for Hydration Behaviour}

XRD is a technique used to determine the composition of crystalline phases in a material [30]. The presence of different phases present in samples was analysed using XRD (PANalytical XPERT-PRO Diffractometer) in $2 \theta$ range between $10^{\circ}$ and $70^{\circ}$. The samples to be analysed were thoroughly ground to fine powder, sieved through $150-\mu \mathrm{m}$ sieve prior to characterization was used for XRD testing.

\section{Specimen Preparation and Testing Procedures}

\section{Unconfined Compressive Strength and Split-Tensile Strength Tests}

The unconfined compression tests and the split-tensile tests were carried out in accordance with ASTM D5102-09 (ASTM 2009b) and ASTM C496-11 (ASTM 2011b), respectively. Similar procedure was followed for specimen preparation as presented in authors' publication [26]. The samples were tested after a curing time of 7,14 and 28 days. The split tensile strength was calculated as.

$T=\frac{2 P \max }{\Pi \cdot L \cdot D}$

where $T=$ split tensile strength; Pmax $=$ maximum applied load; and $L$ and $D=$ length and diameter of the specimen, respectively.

Table 1 Detail of pond ash-soil-cement-fibers tests conducted

\begin{tabular}{lllll}
\hline$W=W_{\mathrm{P}}+W \mathrm{~s}+W_{\mathrm{C}}+W_{\mathrm{f}}$ & $\begin{array}{l}\text { Variation of } W_{\mathrm{P}}(\% \text { by } \\
\text { total dry weight })\end{array}$ & $\begin{array}{l}\text { Variation of } W_{\mathrm{S}}(\% \text { by } \\
\text { total dry weight })\end{array}$ & $\begin{array}{l}\text { Variation of } W_{\mathrm{c}}(\% \text { by } \\
\text { total dry weight })\end{array}$ & $\begin{array}{l}\text { Variation of } W_{\mathrm{f}}(\% \text { by } \\
\text { total dry weight })\end{array}$ \\
\hline Combination 1 & 0 & $100,98,96,94$ & $0,2,4,6$ & 0 \\
Combination 2 & $0,10,20,30,40,50$ & $100,90,80,70,60,50$ & 0 & 0 \\
Combination 3 & $0,10,20,30,40,50$ & $100,90,80,70,60,50$ & 2 & 0 \\
Combination 4 & $0,10,20,30,40,50$ & $100,90,80,70,60,50$ & 4 & 0 \\
Combination 5 & $0,10,20,30,40,50$ & $100,90,80,70,60,50$ & 6 & 0 \\
Combination 6 & 40 & $53.5,53,52.5,52$ & 6 & $0.5,1,1.5,2$ \\
\hline
\end{tabular}




\section{Specimen Preparation and Testing Procedures}

\section{California Bearing Ratio Test}

Same procedures were followed for the preparation of specimen as in case of UCS and STS tests. The CBR test on stabilized soil specimens was conducted (ASTM 2000d). The specimens were made in the CBR mould with the same compactive energy per volume as in the modified Proctor compaction test. Penetration testing was carried out with the help of a plunger of cross-sectional area of $19.35 \mathrm{~cm}^{2}$. The rate of penetration was $1.27 \mathrm{~mm} / \mathrm{min}$. The CBR value was calculated corresponding to $2.54 \mathrm{~mm}$ penetration, because this was always higher than the value obtained at a penetration of $5.08 \mathrm{~mm}$.

\section{Result and Discussion}

Results obtained from these tests are presented in the following sections.

\section{Surface Morphological Characteristics and EDS Result of the Specimen}

Figure 2 shows the SEM images of PA. In terms of the shape and surface characteristics of the particles, Pond ash particles were observed to be spherical in nature (Fig. 2). The surfaces of the particles were observed to be essentially free of dust, clean and shiny.

Figures $3 a, b$ represent the surface morphology of soil + PA + cement mixture after 7 days curing, in which the platy shaped particles of kaolin clay (soil) and spherical or rounded particles of PA were observed. Figure $3 \mathrm{c}, \mathrm{d}$ respectively presents the EDS spectrum and elemental

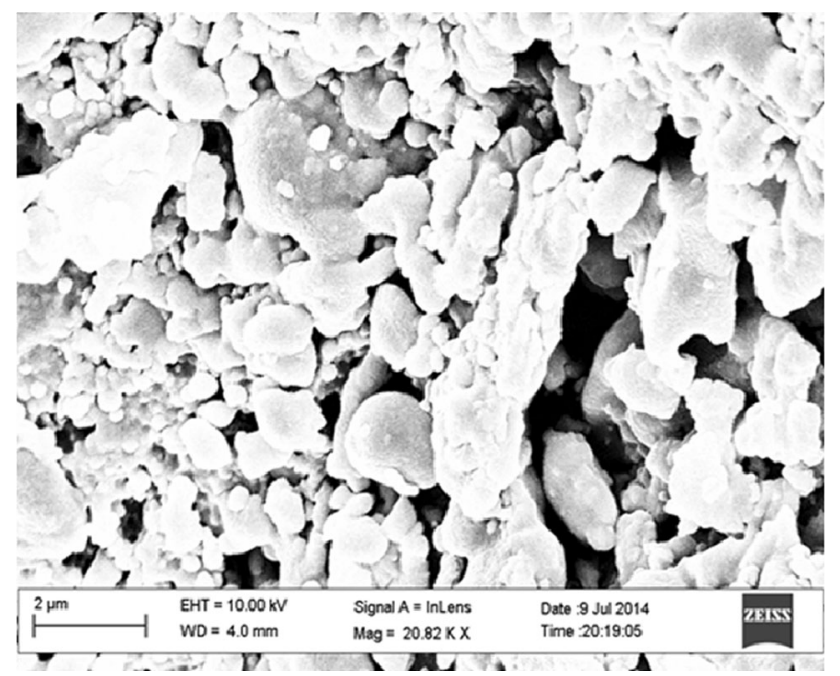

Fig. 2 Scanning electron micrographs (SEM) of pond ash composition of soil $+\mathrm{PA}+$ cement. The effect of addition of cement as additional stabilizing agent cement, show the formation of huge amounts of $\mathrm{C}-\mathrm{S}-\mathrm{H}$ (calcium-silicate-hydrate) phase in form of gel, along with elongated crystalline structures. This hydration is attributed to the formation of pozzolanic reaction and additional stabilization of clay.

\section{XRD Results of the Specimens}

Figure 4 shows the comparison of XRD pattern of Soil + PA and soil + PA + cement after 7 days of curing. It can be observed that treatment of kaolin clay (soil) with cement as an additional stabilizing agent reduces the relative quantities of kaolinite $(\mathrm{K})$ and Quartz $(\mathrm{Q})$. This can be confirmed from the disappearance of peaks or the fall in the intensities of the corresponding peaks. Pozzolanic action of cement can be visualized from the simultaneous appearance of new peaks which are attributed to the presence of pozzolanic product i.e. Calcite $\left(\mathrm{CaCO}_{3}\right)$.

\section{Results of Compaction Test}

Figures 5 and 6 show the change in OMC and MDD values for PA stabilized soil samples respectively. Addition of PA at increasing dosages of $10-50 \%$ in clay tends to increase the OMC and simultaneous decrease of MDD. The specific gravity of PA particles is lower than that of clay which is a prime factor in the reduction of MDD values of PA stabilized soil samples. Further addition of cement to PA stabilized soil leads to a decrease in MDD and increase in OMC, when cement is added at a dosage of 2 and $4 \%$. The extra water is required for higher fineness and subsequent enhanced hydration and reduction in MDD is attributed to flocs formation and base-exchange aggregation.

\section{Results of Unconfined Compressive Strength Test}

The results of UCS tests performed on PA stabilized clay treated with different percentages of cement are presented in Fig. 7. It has been observed that increase in percentage of PA up to $40 \%$ leads to an increase in the UCS values and thereafter the values undergo a decrease. With addition of cement $0-6 \%$ in clay, UCS value increases from 110 to $152 \mathrm{kPa}$, whereas with the addition of $0-6 \%$ cement in PA mixed with clay, UCS increases from 166 to $209 \mathrm{kPa}$. The increase in UCS has been attributed to the cohesion and simultaneous mobilization of frictional component with PA when mixed with the clay. Besides, the additional contribution comes from the admixtures which provide better packing of particles. The obtained results correlate well with those of previous investigations on clay mixed with FA [29, 31]. However, the reduction in values of UCS with 
Fig. 3 a SEM image of soil + PA + cement at $\times 3000$. b SEM image of

soil + PA + cement at $\times 4500$. c EDS spectrum of soil + PA + cement and its elemental composition (table on right) after 7 days curing
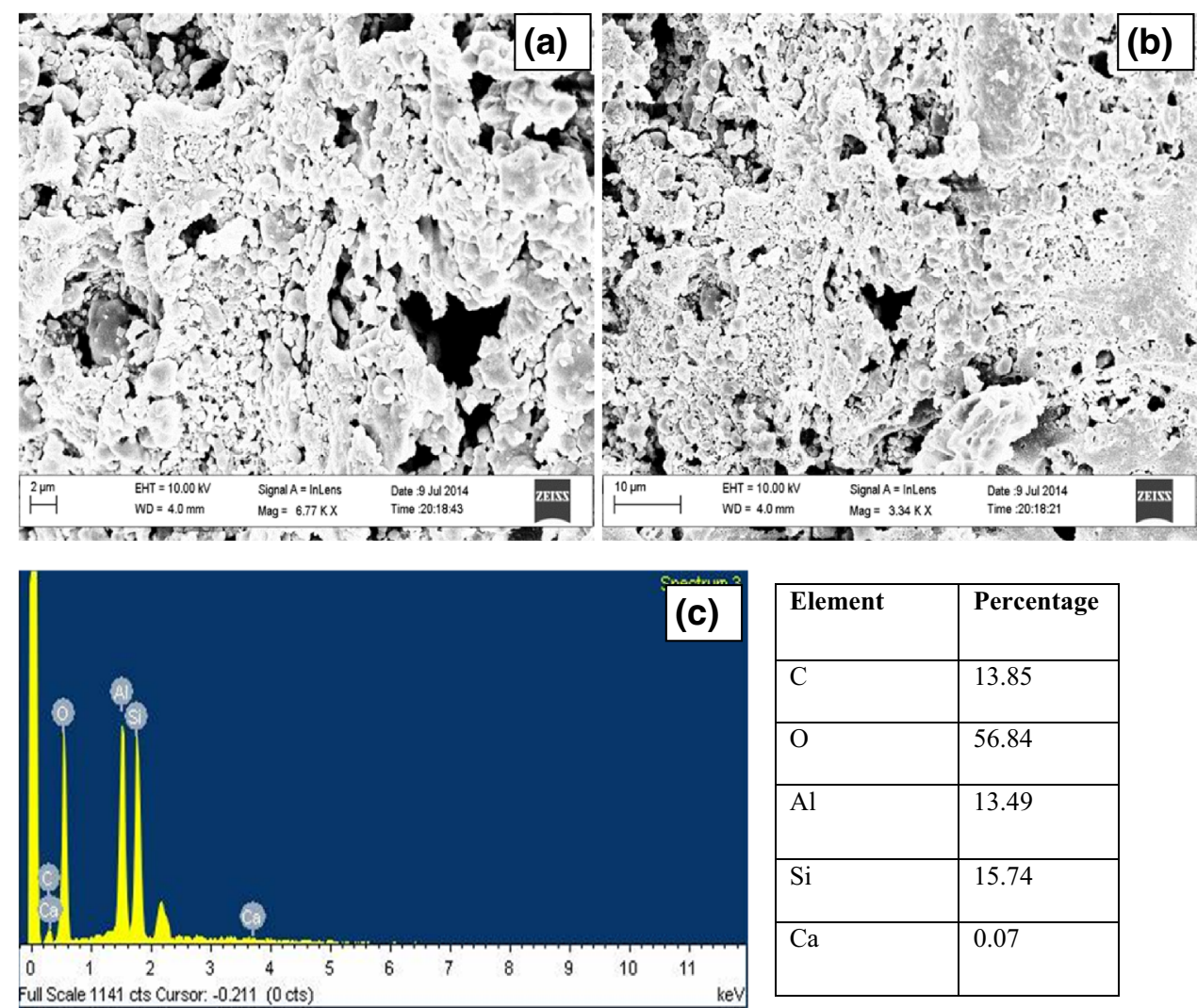

\begin{tabular}{|l|l|}
\hline Element & Percentage \\
\hline $\mathrm{C}$ & 13.85 \\
\hline $\mathrm{O}$ & 56.84 \\
\hline $\mathrm{Al}$ & 13.49 \\
\hline $\mathrm{Si}$ & 15.74 \\
\hline $\mathrm{Ca}$ & 0.07 \\
\hline
\end{tabular}

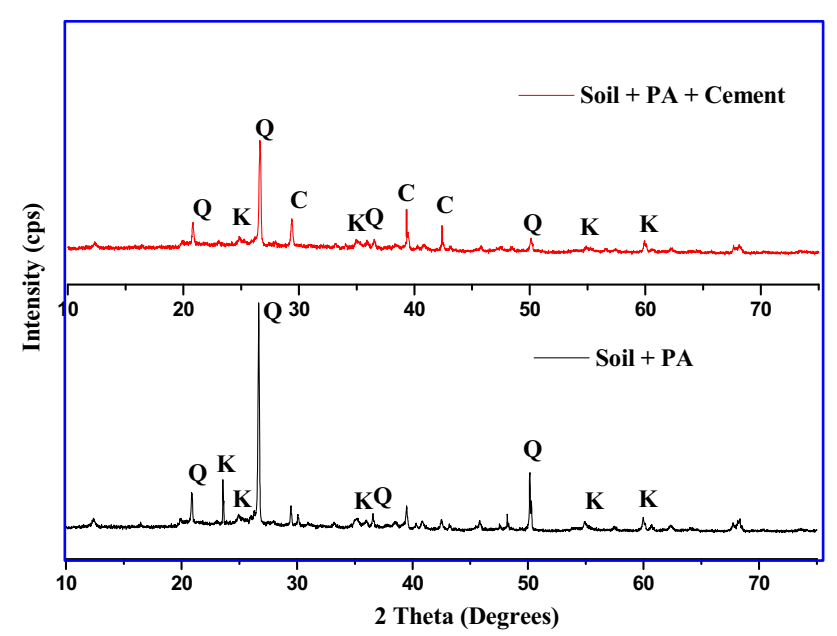

Fig. 4 XRD patterns of clay treated with pond ash

addition beyond $40 \%$ PA has been correlated with the formation of weak ponds between the soil and the cementitous compounds formed [32]. The similar test results have also been reported by previous researchers [32-39].

In Fig. 6, MDD decreases with the increase in the percentage of pond ash and the value of UCS increases (Fig. 7) even though the value of MDD decreases it is due to the reason that pond ash used in this study has size

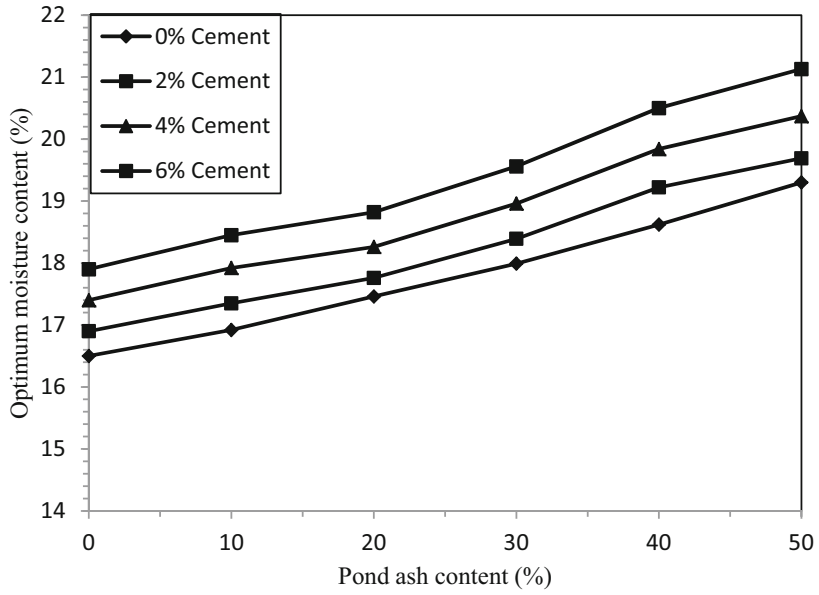

Fig. 5 Optimum moisture content versus pond ash content (\%) with different $(\%)$ of cement

comparable to size of sand, whereas clay is comparable to fine particles. Mixture of these two materials has better gradation. The combined mix with better gradation contributes to greater frictional resistance. Because of this reason the combination have greater potential to improve the strength of clay.

The effect of curing on UCS of the samples is presented in Figs. 8, 9 and 10. With increasing curing period, the strength of pond ash-soil-cement mixtures has been found 


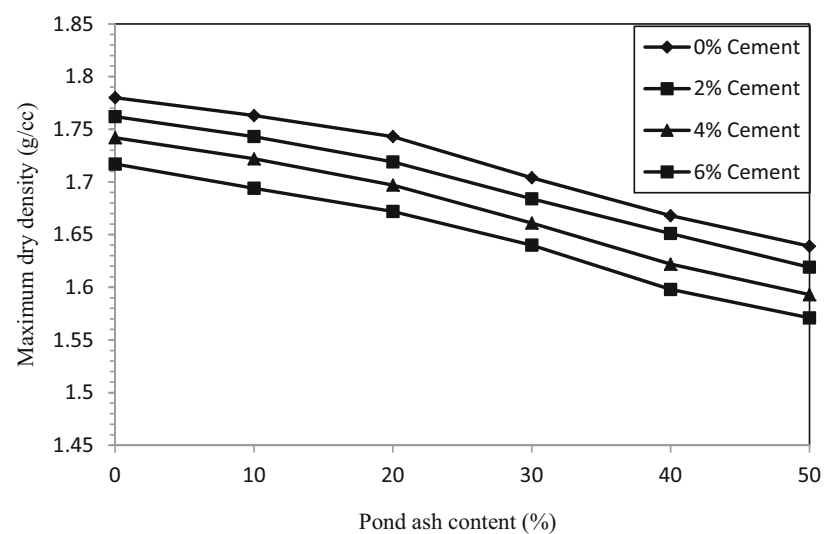

Fig. 6 Dry density versus pond ash content (\%) with different $\%$ of cement

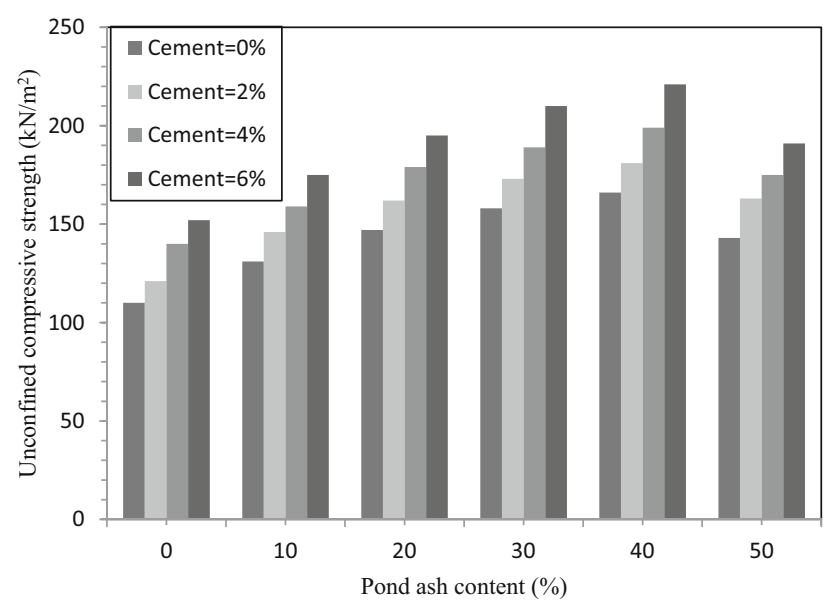

Fig. 7 Variation of unconfined compressive strength with percentage of pond ash content $(\%)$ for different percentages of cement ( 0 days curing)

to increase. The combined effects of cementing and pozzolanic properties of PA-cement stabilized soils lead to higher strength behaviour in comparison to natural soil samples. The chemical reactions that occur when pond ash is mixed with clay include pozzolanic reactions, cation exchange, carbonation and cementation. These result in agglomeration in large size particles. This causes the increase in compressive strength.

Specimens were prepared as per Combination 6 (Table 1) and tested after a curing time of 28 days. Figure 11 shows that the improvement in unconfined compressive strength is approximately 56-66\% with the inclusion of different percentage of fibers. It is proposed that increasing fiber concentration leads to an increase in the interface between the fibers and soil particles thereby increasing the friction between the two. It consequently makes the soil particles difficult to change their position around fibers from one point to another [40].

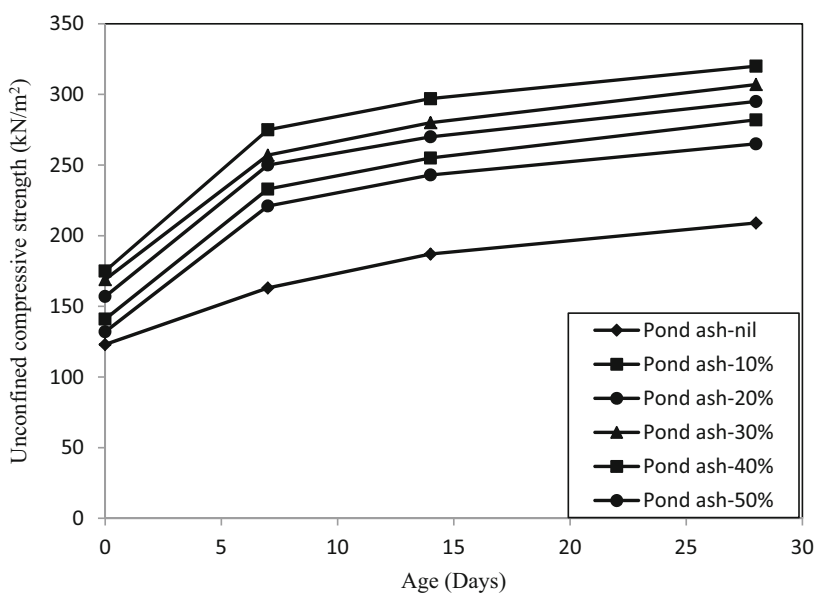

Fig. 8 Variation of unconfined compression strength with age (days) for different percentages of pond ash with $2 \%$ cement

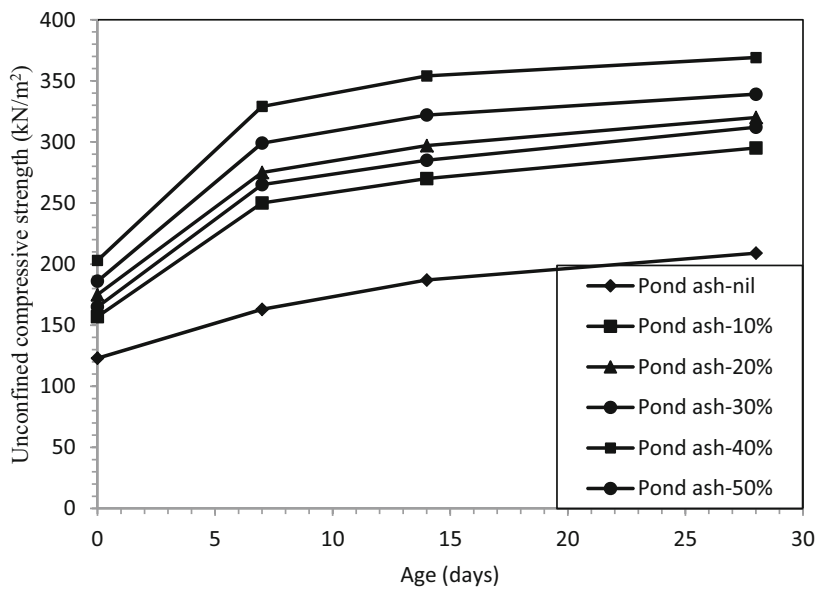

Fig. 9 Variation of unconfined compression strength with age (days) for different percentages of pond ash with $4 \%$ cement

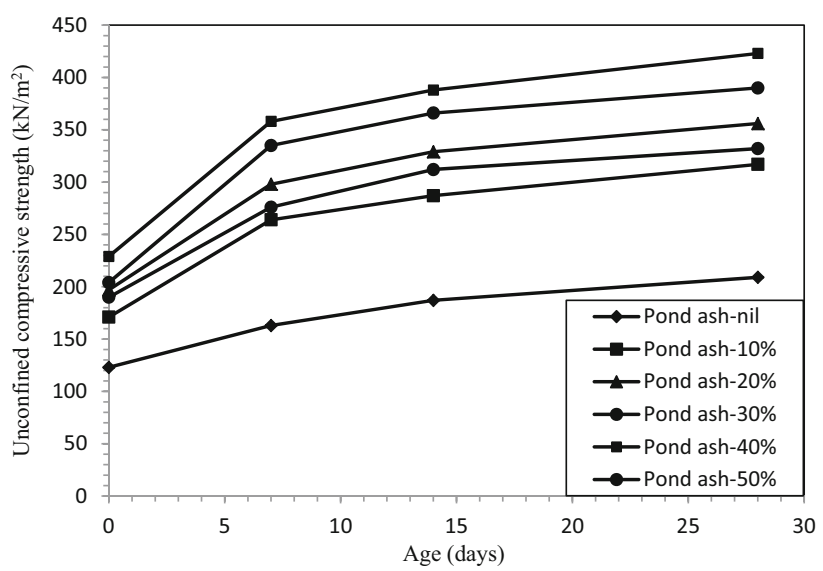

Fig. 10 Variation of unconfined compression strength with age (days) for different percentages of pond ash with $6 \%$ cement 


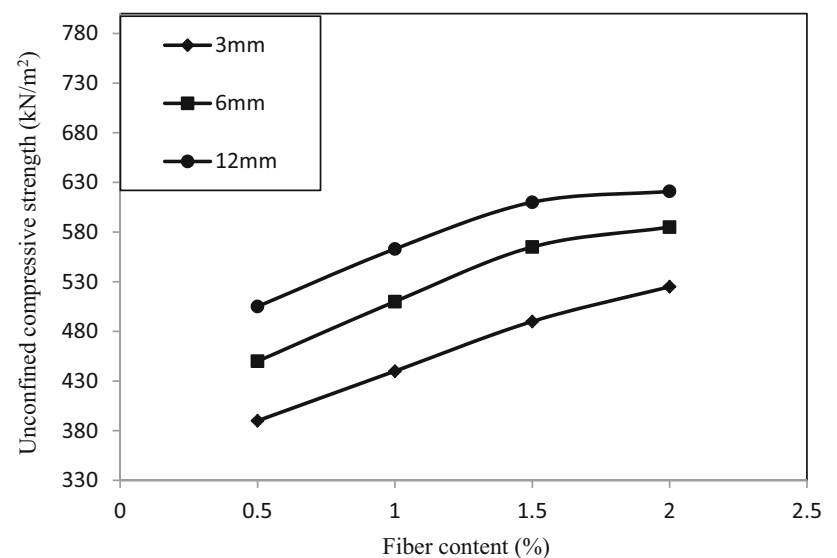

Fig. 11 Variation of unconfined compressive strength with fiber content $(\%)$, for soil mixed with $6 \%$ of cement and $40 \%$ pond ash

\section{Split Tensile Strength Tests (STS)}

Figure 12 shows the effects of PA on STS of clay specimens for varying cement contents. The split tensile strength increased with increasing cement content for given PA content. For example, the STS were 21, 23, 24 and $25 \mathrm{kPa}$, respectively, when the cement content was $0,2,4$, and $6 \%$ for a PA content of $40 \%$. The STS increases with the increase in the cement content from 0 to $6 \%$ at a PA content of $40 \%$. This indicates that $6 \%$ was the optimum content for cement in PA-blended clays. For given cement content, STS increased with increasing PA content. However, a PA content of $40 \%$ gave the maximum value of STS for all cement contents. Split tensile strength decreased when PA content was increased to $50 \%$ irrespective of cement content, thus, indicating that $40 \%$ was the optimum PA content for clay-cement blends.

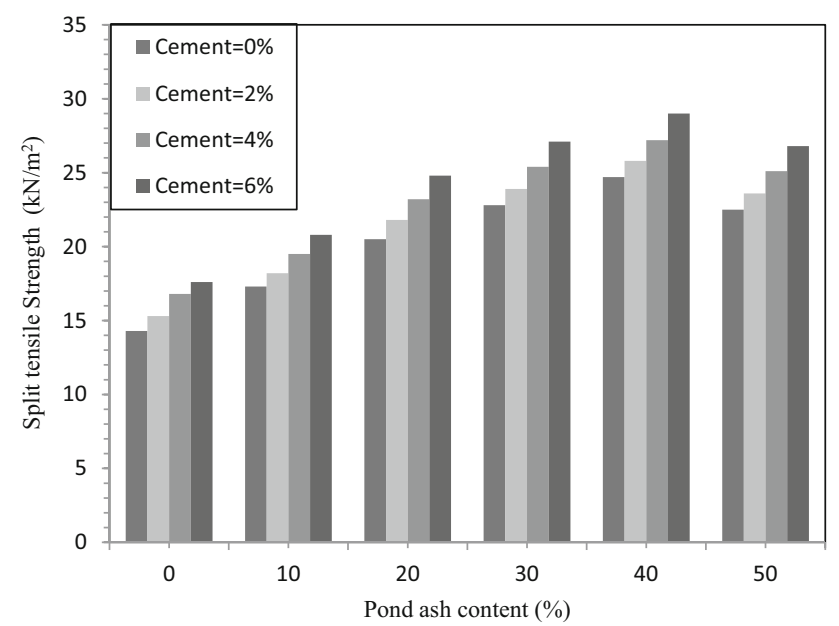

Fig. 12 Variation of split tensile strength with percentage of cement for different percentages of pond ash ( 0 days curing)
Figures 13, 14, 15 show the effect of curing on the split tensile strength of the samples, showing that the strength increased as the curing period increased. In addition, it can be observed that the split tensile strengths of pond ashsoil-cement blend after 7, 14, and 28 days of curing period are always higher than those of respective pond ash-soil samples.

Specimens were prepared as per Combination 6 (Table 1) and tested after a curing time of 28 days. Figure 16 shows that the improvement in split tensile strength is approximately $49-65 \%$ with the inclusion of different percentage of fibers.

\section{California Bearing Ratio Test (CBR test)}

Figure 17 shows the 4-day CBR values for un-stabilized and stabilized soil mixtures. The un-stabilized soil had the smallest CBR value of $2.5 \%$, when subjected to 4 days of

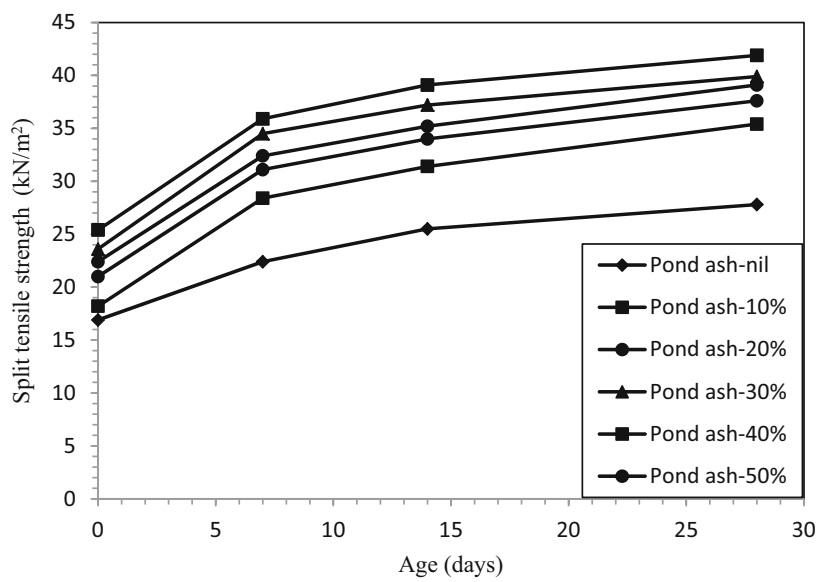

Fig. 13 Variation of split tensile strength with age (days) for different percentages of pond ash with $2 \%$ cement

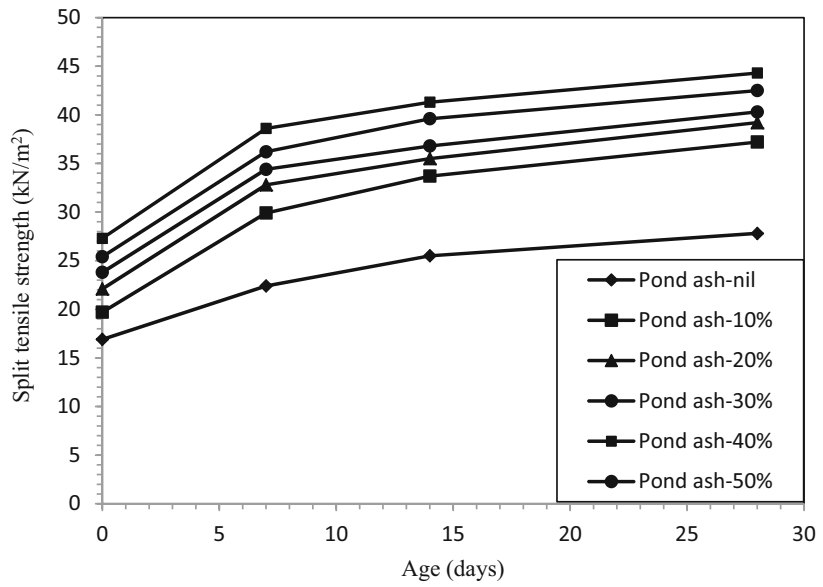

Fig. 14 Variation of split tensile strength with age (days) for different percentages of pond ash with $4 \%$ cement 


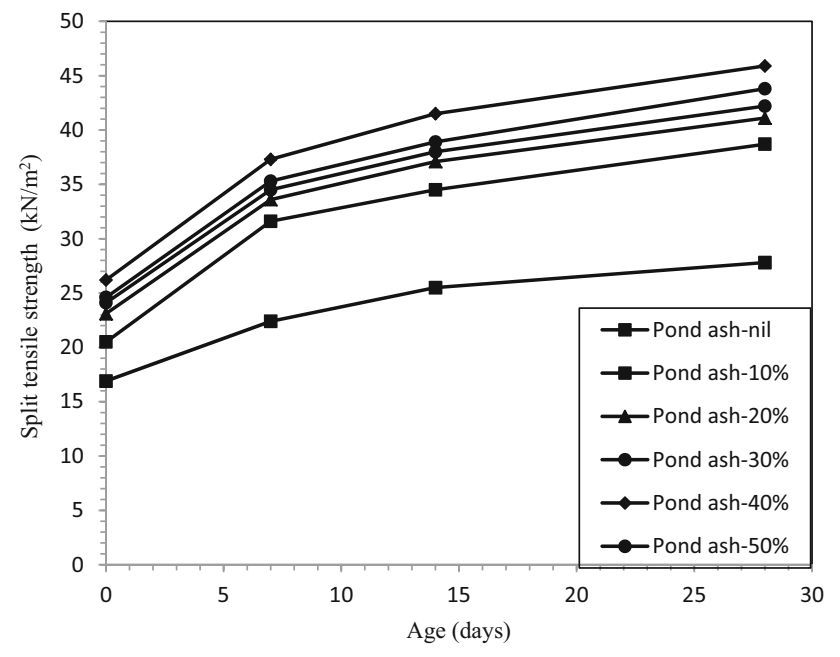

Fig. 15 Variation of split tensile strength with age (days) for different percentages of pond ash with $6 \%$ cement

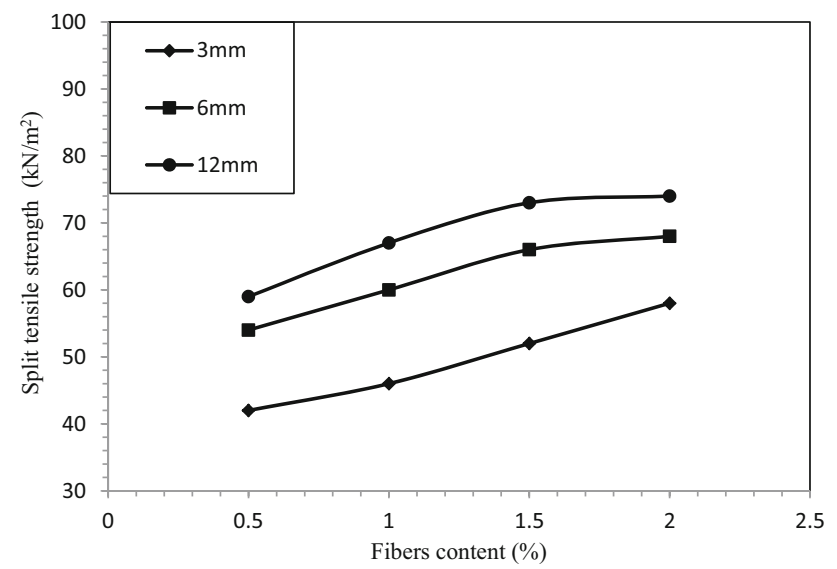

Fig. 16 Variation of split tensile strength with fibers content (\%), for soil mixed with $6 \%$ of cement and $40 \%$ pond ash

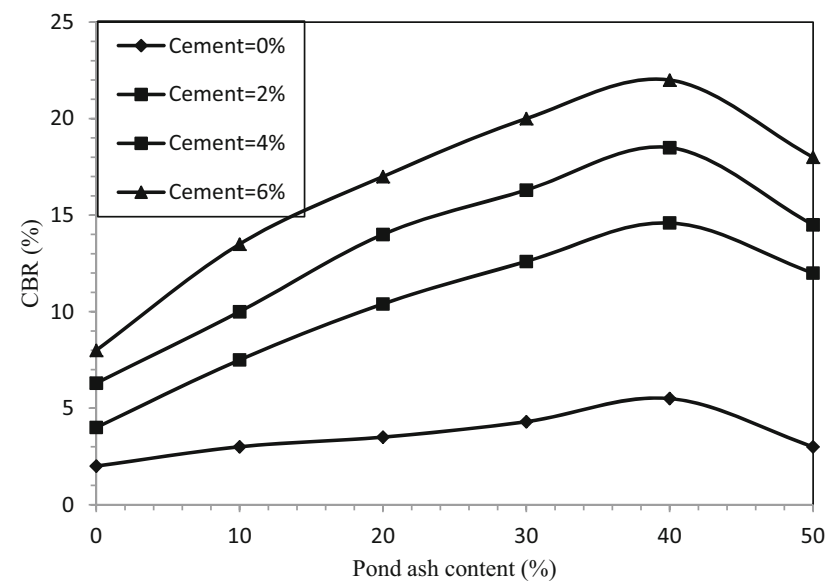

Fig. 17 Variation of California bearing ratio (\%) with pond ash content with different percentages of cement water immersion. The addition of $40 \% \mathrm{PA}$ and $6 \%$ cement to clay increases the soaked CBR value from 2.5 to $30 \%$. The reason for the CBR improvement was because of the cementing pozzolanic reaction between the soil and cement/RHA material. The chemical hydration during the reaction, regarded as the primary reaction, formed additional cementitous material that bound particles together and enhanced the strength of the soil.

Specimens were prepared as per Combination 6 (Table 1) and tested after a soaking period of 4 days. Figure 18 shows that there is improvement of CBR value by approximately $70 \%$ with inclusion of $1.5 \%$ of $12 \mathrm{~mm}$ fibers as compared to that of same mixture without fibers. The CBR values increased with an increase in the amount of fiber up to $1.5 \%$, and thereafter the CBR decreased slightly with the further addition of fibers (Fig. 18). The increase in CBR value was attributable to the fact that fibers contributed significantly to enhance the bearing capacity of the stabilized soil. The decrease in CBR value is due to the interaction between the soil and the fiber reinforcement controlled the response of the soil/fiber mixture to compaction [40].

\section{Statistical Analyses}

\section{Multiple Linear Regression Analysis (MLRA)}

In engineering and sciences, many problems involve investigating the relationship between two or more problems. Multiple linear regression analysis (MLRA) is a linear statistical that is very beneficial for predicting the best relationship between a dependent variable and several independent variables. MLRA is based on least squares: the model is fit such that the sum of squares of differences of

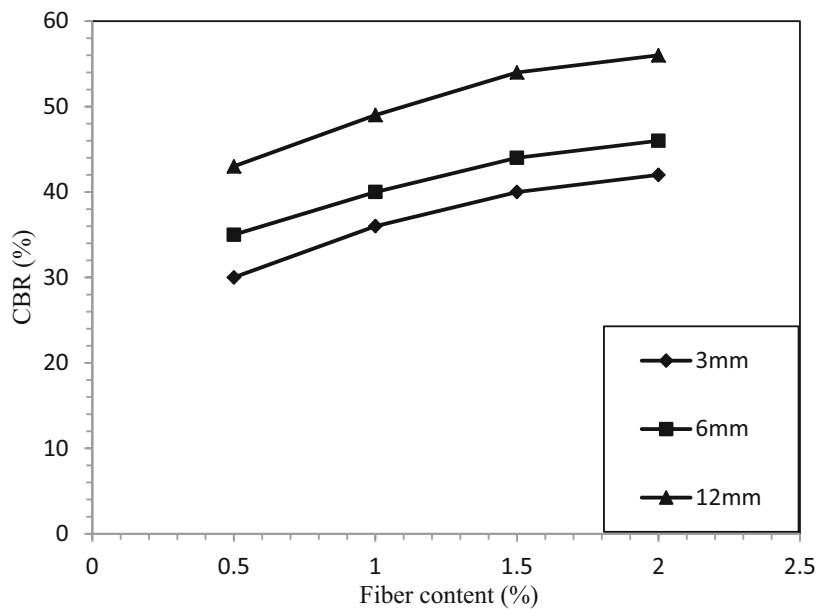

Fig. 18 Variation of California bearing ratio (\%) with fiber content (\%) 
observed and predicted values in minimized. MLR analysis was carried out using SPSS software. A general MLRA model can be formulated as the following equation.

$Y=\beta_{0}+\beta_{1} X_{1}+\cdots+\beta_{n} X_{n}+\varepsilon$

where $Y$ indicates dependent variable, $X_{i}$ represents independent variables, $\beta_{i}$ represent predicted parameters and $\varepsilon$ is the error.

Regression analysis of unconfined compression strength test data was done to compute the value of unconfined compression tests against the percentage of clay, rice husk ash, pond ash and cement. A statistical model has been developed based on present experimental data for predicting the value of unconfined compression strength $\left(\mathrm{UCS}_{\mathrm{P}}\right)$ and split tensile strength $\left(\mathrm{STS}_{\mathrm{P}}\right)$ tests of clay stabilized with the combination of pond ash cement and fibers. Multiple linear regression analysis was done, where the dependent variable was predicted unconfined compression strength $\left(\mathrm{UCS}_{\mathrm{P}}\right)$ and split tensile strength $\left(\mathrm{STS}_{\mathrm{P}}\right)$ tests.

The various independent variables considered for regression analysis were as follows:

1. Percentage of clay in mix $(\mathrm{Cl})$.

2. Percentage of pond ash in mix (PA).

3. Percentage of cement $(C)$.

4. Curing period in days $(\mathrm{CP})$.

The equation for predicted values obtained is given below:

$$
\begin{aligned}
(\mathrm{UCS})_{\mathrm{P}}= & 169.4-(0.67 \times \mathrm{Cl})+(1.01 \times \mathrm{PA})+(11.52 \\
& \times C)+(4.7 \times \mathrm{CP}) \\
(\mathrm{STS})_{\mathrm{P}}= & (33.3)-(0.17 \times \mathrm{Cl})+(0.054 \times \mathrm{PA})+(0.51 \\
& \times C)+(0.55 \times \mathrm{CP})
\end{aligned}
$$

For Eqs. (1) and (2) the value of relevant statistical coefficient like coefficient of determination, $R^{2}$ is found to be 0.73 and 0.80 respectively. The linear scatter diagram using Eqs. (3) and (4) is shown in Figs. 19 and 20 respectively. It may be observed that regression plot of predicted UCS and STS value against the experimental UCS and STS of testing data points lies well within the $99 \%$ confidence interval.

\section{Conclusions}

The current study reports the behaviour of fibre reinforced and cement stabilized cement mixed with pond ash using various tests such as modified Proctor compaction tests, unconfined compressive strength tests, split tensile strength tests and California bearing ratio tests were done to

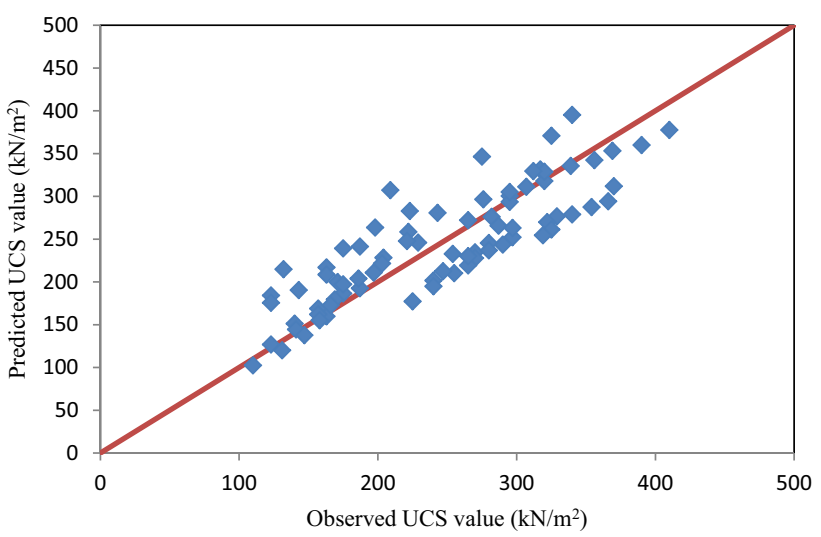

Fig. 19 Cross-correlation of predicted and observed UCS values for multiple regression model

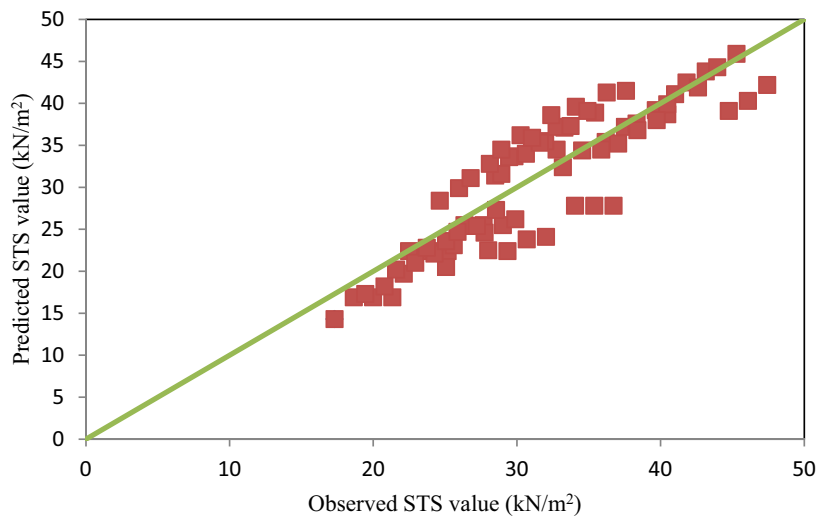

Fig. 20 Cross-correlation of predicted and observed STS values for multiple regression model

evaluate the behaviour of the fibre reinforced and cement stabilized soil mixed with pond ash. The important concluding remarks made from the present investigation have been given below.

- The MDD of cement-stabilized soil-pond ash mix slightly decreases from 1.78 to $1.64 \mathrm{~g} / \mathrm{cc}$ and OMC increases from 18.45 to $21.13 \%$, with the increase in cement content from 0 to $6 \%$.

- The stabilization of the clay-pond ash with cement alone or in conjunction with polypropylene fibers is effective in enhancing the UCS, STS and CBR parameters. Slight addition of cement in clay-pond ash enhances its performances and reinforcement with fiber further increases its strength.

- The effect of cement and fiber contents along with the curing period is significant on the performance evaluation of cement stabilized and fiber reinforced claypond ash mixes. The addition of $1.5 \%$ fiber of $12 \mathrm{~mm}$ in the mix is found to yield optimum performance. Further, the use of cement beyond $6 \%$ shall although enhance the strength, will not be economically viable. 
- Microstructure analyses from XRD and SEM indicate that the addition of $6 \%$ cement accelerated the production of calcium hydroxide and $\mathrm{C}-\mathrm{S}-\mathrm{H}$ gel. Hydration products also increased. This observation suggests that the UCS, STS and CBR values of treated soil could be improved by adding cement.

- The brittle behavior is exhibited by the pond ash-soil specimens compacted at the MDD-OMC state. The brittle behaviour is more obvious in cement stabilized specimens in comparison to the un-stabilized specimens. However, the incorporation of fibers changes the brittle behavior to ductile behaviour.

- An increase in curing period increases the strength (UCS and STS). This is attributed to the formation of pozzolanic reaction with the addition of cement. In comparison to un-stabilized soil, the cement stabilized soil exhibited a strength enhancement of $311 \%$ after 7 days of curing.

- The stress versus strain curves reveal that at the $12 \mathrm{~mm}$ size fiber gives higher strength than 3 and $6 \mathrm{~mm}$ size fibers. Strength improvement is found $150 \%$ at optimum length and content of fiber.

- CBR value of the mix increases with increase in the content of the cement to a certain limit of fiber content $(\mathrm{FC}=1.5 \%)$ known as optimum content, after which further improvement in the CBR is not significant.

- There has been a remarkable improvement of the CBR value with the admixture of pond ash and cement. The CBR value was sixfold the initial one with the addition of pond ash at a content of $40 \%$ by weight. The increase in CBR as a function of the pond ash content could be attributed to the pozzolanic activity of the pond ash. Such a use of pond ash would also have the benefit of depositing a thermal power plant byproduct without negatively affecting the environment.

- Multiple linear regression analysis was done for finding the predicted unconfined compression strength (UCSp) and split tensile strength (STSp), which matches well with the experimental values.

\section{References}

1. Beeghly JH (2003) Recent experiences with lime: fly ash stabilization of pavement subgrade soils, base, and recycled asphalt. In: International ash utilization symposium, University of Kentuchy, Center for Applied Energy Research, Lexington

2. Gray DH, Tons E, Thiruvengadam TR (1994) Performance evaluation of a cement-stabilized fly ash base. Trans Res Rec 1440:8

3. Shirazi H (1999) Field and laboratory evaluation of the use of lime fly ash to replace soil cement as a base course. Trans Res Rec 1652(1):270-275

4. Andersland OB, Khattak AS (1979) Shear strength of kaolinite/fibre soil mixture. Proc 1st Int Conf Soil Reinf 1:11-16
5. Freitag DR (1986) Soil randomly reinforced with fibers. J Geotech Eng 112(8):823-825

6. Setty KRNS, Rao SVG (1987) Characterisation of fiber reinforced lateritic soil. IGC, Bangalore, pp 329-333

7. Maher MH, Gray DH (1990) Static response of sands reinforced with randomly distributed fibers. J Geotech Eng 116(11):16611677

8. Al-Refeai TO (1991) Behaviour of granular soils reinforced with discrete randomly oriented inclusions. Geotext Geomembr 10:319-333

9. Fatani MN, Bauer GE, Al-Joulani N (1991) Reinforcing soil with aligned and randomly oriented metallic fibers. ASTM, West Conshohocken, pp 78-87

10. Maher MH, Ho YC (1994) Mechanical properties of kaolinite/fiber soil composite. J Geotech Eng 120(8):1381-1393

11. Michalowski RL, Zaho A (1996) Failure of fiber-reinforced granular soils. J Geotech Eng 122(3):226-234

12. Ranjan G, Vasan RM, Charan HD (1996) Pobabilistic analysis of randomly distributed fiber reinforced soil. J Geotech Eng 122(6):419-426

13. Consoli NC, Prietto PDM, Ulbrich LA (1998) Influence of fiber and cement addition on behavior of sandy soil. J Geotech Geoenviron Eng 124:1211-1214

14. Consoli NC, Montardo JP, Prietto PDM, Pasa GS (2002) Engineering behavior of sand reinforced with plastic waste. J Geotech Geoenviron Eng 128(6):462-472

15. Santoni RL, Tingle JS, Webster S (2001) Engineering properties of sand fiber mixtures for road construction. J Geotech Geoenviron Eng 127(3):258-268

16. Kumar A, Walia BS, Mohan J (2005) Compressive strength of fiber reinforced highly compressible clay. Constr Build Mater 10(20):1063-1068

17. Consoli NC, Casagrande MDT, Coop MR (2005) Effect of fiber reinforcement on the isotropic compression behaviour of sand. J Geotech Geoenviron Eng 131:1434-1436

18. Casagrande MDT, Coop MR, Consoli NC (2006) Behaviour of fiber reinforced bentonite at large shear displacement. J Geotech Geoenviron Eng 132(11):1505-1508

19. Casagrande MDT, Consoli NC, Coop MR (2007) Performance of a fiber reinforced sand at shear strains. Geotechnique 57:751756

20. Casagrande MDT, Consoli NC, Hieneck KS, Coop MR (2007) Shear strength behavior of fiber-reinforced sand considering triaxial tests under distinct stress paths. J Geotech Geoenviron Eng 133(11):1466-1469

21. Park SS (2008) Effect of fiber reinforcement and distribution on unconfined compressive strength of fiber-reinforced cemented sand. Geotext Geomembr 27:162-166

22. Anggraini V, Asadi A, Huat BK, Nahazanan H (2014) Effects of coir fibers on tensile and compressive strength of lime treated soft soil. Measurement 59:372-381

23. Chand SK, Subbarao C (2007) Strength and slake durability of lime stabilized pond ash. J Mater Civil Eng 19:601-608

24. Sarkar R, Abbas SM, Shahu JT (2012) A comparative study of geotechnical behaviour of lime stabilized pond ashes from Delhi region. Int J Geomate 1(3):273-279

25. Bera AK, Ghosh A, Ghosh A (2007) Behavior of model footing on pond ash. Goetech Geol Eng 25:315-325

26. Kumar A, Gupta D (2016) Behaviour of cement stabilized fiberreinforced pond ash, rice husk ash-soil mixtures. Geotext Geomembr 44(3):466-474

27. Roy TK, Chattopadhyay BC (2008) A study on the effect of cement on alluvial soil strengthened with pond and rice husk ash for construction of road subgrade. The 12th international conference of international association for computer methods and advances in geomechanics (IACMAG) 1-6 October, Goa 
28. Ghosh A (2010) Compaction characteristics and bearing ratio of pond ash stabilized with lime and Phosphogypsum. J Mater Civil Eng ASCE 22(4):343

29. Pandian NS, Krishna KC, Sridharan A (2001) California bearing ratio behavior of soil/fly ash mixtures. J Test Eval JTEVA 29(2):220-226

30. Sharma S, Kothiyal NC (2015) Influence of grapheme oxide as dispersed phase in cement mortar matrix in defining the crystal patterns of cement hydrates and its effect on mechanical, microstructural and crystallization properties. RSC Advances 5(65):52642-52657

31. Pandian NS, Krishna KC (2003) The Pozzolanic effect of fly ash on the California bearing ratio behavior of black cotton soil. J Test Eval 31(6): 1

32. Alhassan M (2008) Potentials of rice husk ash for soil stabilization. AU J Technol 11(4):246-250

33. Ali FH (1992) Stabilisation of a residual soil. Soil Found 32(4):178-185
34. Jha JN, Gill KS (2006) Effect of rice husk ash on lime stabilization. J Inst Eng 87:33-39

35. Brooks RM (2009) Soil stabilization with fly ash and rice husk ash. Int J Res Rev Appl Sci 3(1):209-217

36. Muntohar AS (2002) Utilization of uncontrolled burnt rice husk ash in soil improvement. Dimensi Teknik Sipil 2(4):100-105

37. Rahman MA (1987) Effect of cement-rice husk ash mixtures on geotechnical properties of lateritic soils. Soils Found 27(2):61-65

38. Miller G, Azad S (2000) Influence of soil type on stabilization with cement kiln dust. Constr Build Mater 14(2):89-97

39. Tang CS, Shi B, Gao W, Chen FJ, Cai Y (2007) Strength and mechanical behavior of short polypropylene fiber reinforced and cement stabilized clayey soil. Geotext Geomembr 25(3):194-202

40. Nataraj MS, McManis KL (1997) Strength and deformation properties of soils reinforced with fibrillated fibers. Geosynth Int 4(1):65-79 